\title{
The Formation of Professional Music Education in the System of Academic Traditions in Yeniseisk Province
}

\author{
Evgenya Tsareva \\ Krasnoyarsk State Institute of Arts \\ Krasnoyarsk, Russia \\ E-mail: evatcareva@gmail.com
}

\author{
Maria Chikhacheva \\ Krasnoyarsk State Institute of Arts \\ Krasnoyarsk, Russia \\ E-mail: mgokhfeld@yandex.ru
}

\begin{abstract}
The case study presented in the article analyzes unpublished archive materials and scientific papers to investigate the role that music education has played in the formation of regional system of academic traditions in Yeniseisk Province. The authors examine professional music education establishing in Krasnoyarsk region in the period of imperial and Soviet past. Analyzing local materials from social and cultural perspectives gives new results in the study of historical events. Along with that, it illuminates the importance of self-organizational processes in the development of regional culture and fully covers the role of musical and educational institutions in successful development of the academic model in Yeniseisk province in the light of "center-periphery" problem.
\end{abstract}

Keywords-academic musical traditions; music education; self-organization; center; periphery; Yeniseisk Province

\section{INTRODUCTION}

For a long time, Siberia has been observed as the land of folk traditions. Due to this fact, its ethnic music has been deeply studied; however, the academic art in the region has its own past and also requires attention of researchers. A significant role in the national cultural space belongs to Krasnoyarsk Krai, possessing an extensive system of functioning of academic art which has many universal (allRussian and common Siberian) and some specific features as well.

Academic tradition, regardless of the areas they were formed in (by virtue of its genesis), are based on the norms and patterns of musical language and thinking prevailing in the European professional writing art of modern times. The system which originated in Western Europe in the 16th and 17 th centuries, spread to the twentieth century all over the world and has become universal. Its interaction with various traditional cultures has generated numerous national schools of composing. Russian musical culture has formed as a unique version of the pan-European and as one of the world's major events. It had an impact on the deployment of the artistic process globally and locally. The periphery of the country perceived Western European system and its academic form largely through the prism of the Russian version.
Functioning and development of academic traditions in the society requires a complex system of musical communication. Asafiev B.V. pointed out three main components of its base - the activity of the three main subjects: the composer, performer and listener. [1] However, an essential link in the "chain" is an educator. Thus, among the main elements forming the academic musical culture are: composer creativity, performance, listener and education, which in turn become the whole system for the element base of a lower order.

This multicomponent structure, provided that each of the system's elements is developed enough, is a model of functioning of academic art in cultural centers. In the periphery, it is adaptive to local conditions, opportunities and needs. This is reflected in the truncated "set" of its components, specifics of their condition, disparity of development. Formation of these "blocks" occurs out of sync; the sequence of their appearance and spreading is also different according to regional characteristics. Music education plays a special role in the process of expanding the range of functioning of the European cultural system. Consider Krasnoyarsk as an example.

\section{DEVELOPMENT OF ACADEMIC MUSIC TRADITIONS SYSTEM IN YENISEISK PROVINCE}

Future district centers of Yeniseisk Province - Yeniseisk, Krasnoyarsk, Kansk, Achinsk - were founded during the 17 th century $(1619,1628,1636,1683)$ as military fortresses at the stage of development of the region and its accession to the Russian state. They received the city status later: Yeniseisk - in 1676, Krasnoyarsk - in 1690, Kansk and Achinsk - in 1782. Minusinsk was built in peacetime, when raids of Siberian nomadic tribes ceased - in 1739 as a village Minyusinskoe (later - Minusinsk) and became a city in 1822 . The main part of the inhabitants was the Slavs which had come from Russia and Central Europe. Among the rest of the population, a small percentage was formed by Europeans who were often caught and sent to Siberia among the exiles and prisoners of war [26. P. 7]. The dominant factors in dissemination of academic musical traditions in Krasnoyarsk area were two ways of personal mediation: direct, with Europeans playing the role of mediators, and indirect when 
new traditions in the adapted and revised version were transferred by Russians. Even in the 17th century elements of the new musical thinking began to penetrate to Krasnoyarsk area. In the 18th century, with the active dissemination of European musical model beyond its historical emergence and intensive consumption of Western values, information flows coming to Siberia increased, but the "virgin" cultural soil of the region did not allow their "acceptance".

Since the establishment of Yeniseisk Province in 1822, the pace of development of the area significantly accelerated causing the influx of educated population from the European part of the country. Russian economy was developing fast; the bearers of new musical knowledge came to rapidly growing cities of Siberia. The capital (Krasnoyarsk) and district centers (Yeniseisk, Kansk, Achinsk, Minusinsk), accumulating the necessary capacity for the preservation of cultural traditions and the assimilation of innovations were the points of concentration, an active musical life province. Dynamic urban culture with a particular set of needs and the type of artistic thinking started to develop, and modern European art with its own academic forms played the leading role in this process.

In the 19th - early 20th century, the European system of academic art that had confidently declared itself in the world and operating successfully in Russia was "transplanted" (the term of D. Likhachev) [9. P. 6] in the urban space of Yeniseisk Province. Cultural centers brought to Siberia traditions of musical performance, composition, pedagogy, music perception and consumption values. Being borrowed from an external source of culture, they stayed in the new environment, gradually acquiring local components.

Historically, the first is the establishment of performing and the audience. Starting from the second half of the 19th century a local infrastructure of academic performance traditions started to form intensively in the cities of the Province and putting to the area musical values created by Russian and European composers. The foundation and main engine of cultural life were amateur musicians gradually leaving the home for concert halls. Amateur symphony and chamber orchestras, various ensembles, secular choirs were organized, solo concert practice developed. At the same time, new facilities were being constructed, music journalism and criticism were emerging. In addition to the amateur, the first steps were made by professional performing: since the 1870 s at Krasnoyarsk City Theatre instrumental ensembles had been performing at presentation and during intermissions. Improvement of the material-technical base and transport links with the mother country (opening of Trans-Siberian Railway in 1895) are responsible for the increase in the number of professional touring artists coming to Yeniseisk Province.

Surely, it is not possible to claim that the system composition activity in Yeniseisk Province was developing at high level; however, at the turn of 19th-20th centuries, local authors appeared who created music based on the world musical heritage. However, significant composers such as Beznosikov S.M. and Ivanov-Radkevich P.I., creating spiritual, symphony, opera, chamber, vocal and instrumental pieces, can be called "local" only conditionally. They received professional musical education in St. Petersburg ${ }^{1}$ and just lived in Krasnoyarsk for some time. The same trend can be observed in performing sphere formation. Although it included representatives of the local population (mostly amateurs), it "grew" largely with the help of the "outsiders" (political exiles, prisoners of war, secular and military musicians, temporarily living in Siberia). To develop the academic model borrowed from outside, help its reproduction and improvement, make it able to operate in a single geographical area with no permanent donor "infusions" it was needed to create a professional music education system and bring up new professionals.

\section{FORMATION OF PROFESSIONAL MUSIC EDUCATION AND THE ROLE OF SELF-ORGANIZATION PROCESSES IN YENISEISK PROVINCE IN IMPERIAL PERIOD}

Foundation of professional music education system in the academic tradition of Yeniseisk Province was going at a slow pace and significantly lagged behind the development of both the performing and cultural needs of the population, as well as from the neighboring provinces of Siberia - Tomsk, Omsk, Irkutsk. In the imperial period in Krasnoyarsk area this process developed exclusively due to socio-cultural selforganizational mechanisms. Disregard that the government showed towards the development and modernization of the musical culture, absence of external 'vertical' effects in a variety of state support options were compensated by active internal mechanisms of self-regulation, initiated by the advanced part of society - people with the necessary level of education, intelligence, and creativity.

One of the forms of social self-organization in the music culture was music clubs and societies - non-governmental, voluntary and namely amateur associations which included representatives of different social classes. In the Yeniseisk Province, they started to appear in the last quarter of the 19th century. Some of them were: Musical circle (1882), which later grew into a Society of music and literature lovers (1886) in Krasnoyarsk [24. P. 69], Theatrical circle of the late 1870s and Literary and musical-dramatic society created on its base in the early $1880 \mathrm{~s}$ in Minusinsk [8. P. 105], Yeniseisk Society of music and literature lovers (1898) [16, p. 1], Circle (1905) [15] and the Society of lovers of dramatic art, music and singing in Kansk (1907) [23. P. 9] . In addition to the organization of ensembles, special efforts were directed to the creation of special sources of professional music education. The main item in the charter of the Yeniseisk Society of music and literature lovers was "to arrange music classes" [22. P. 2]. The Society had repeatedly considered that serious question at its meetings [12. P. 20] and tried to found a music school in the capital of the province, but unfortunately with no result.

\footnotetext{
${ }^{1}$ Sergey Mikhailovich Beznosikov was born in Yeniseisk Province and lived in Krasnoyarsk $\mathrm{n}$ 1880s. He graduated from St. Petersburg Conservatory, N.A. Rimsky-Korsakov class. Pavel Iosifovich IvanovRadkevich was born and received education in St. Petersburg. He lived in Krasnoyarsk in 1897-1922 [24. P. 269].
} 
Yeniseisk's Governor received a petition from the Chairwoman of the Board of Krasnoyarsk Society of music and literature lovers on June 18, 1897 with request to "open singing and music classes (piano and violin) in Krasnoyarsk" [14. P. 2] and "programme of subjects" attached [14. P. 3]. The classes were designed for four-year training period. The acceptance of the programme had to be received from the Ministry of Internal Affairs and in July 20, 1898 "the opening of the classes was permitted." The Ministry had arranged the permission with the Main Directorate of the Imperial Russian Musical Society (IRMO) ${ }^{2}$, which, in turn, "recognized desirable to supplement the program of classes with elementary theory and ear training manuals" [14. P. 5]. Krasnoyarsk Society of music and literature lovers provided the necessary curriculum ${ }^{3}$ and the list of books [14. P. 8], and in May 1899 "the programme of teaching music classes was approved by Main Directorate of the Imperial Russian Musical Society" [14. P. 11]. Krasnoyarsk Society of music and literature lovers held charity concerts regularly to raise funds in favor of "Opening a music school" [20], but it was not enough. As Ivanov-Radkevich P.I. would later say: "The need for a music school in Krasnoyarsk was not disputed. The opening had been planned in 1899, and only the lack of material resources made it impossible to implement this plan" [10].

In the first decade of the twentieth century there was a decline of activity of Krasnoyarsk Society of music and literature lovers. Gradually, it was closed but in early 1910 was opened once again [11] and immediately put a priority of its work - the foundation of a music school. In February of 1910, the Society started to organize concerts; money got from tickets was directed to the formation of a music classes "fund". Local press posted articles aimed to get money from the most empathic citizens: "Music classes are organized in Krasnoyarsk. We suffer from funds deficiency. But there are good men who are ready to support good initiatives" [5]. The main part of active Krasnoyarsk intellectuals made attempts to create special music classes but the plans were not realized [24. P. 106]. The first permanent musical educational institution in the Yeniseisk Province was opened only after the Bolsheviks had come to power.

The absence of music school in Yeniseisk Province was compensated by private teaching practice and selfdevelopment skills that were also a form of self-organization. The system of public education of Yeniseisk Province gave opportunities to music education: within the lower and middle spiritual, military and secular schools. In closed institutions belonging to the military departments and the Russian Orthodox Church, it was orderly and regulated "from above", depended on the common law regulations. Music and singing lessons were included in the list of compulsory subjects of spiritual and military educational institutions. This provided better stabilization of the educational process, as compared with civilian (especially basic) schools, but, in turn, limited the reception of musical

\footnotetext{
${ }^{2}$ The Krasnoyarsk society of music and literature lovers was not a part of IRMO

${ }^{3}$ The Krasnoyarsk society of music and literature lovers formed a curriculum and listed the books on singing and performing subjects $[14, p .8]$
}

knowledge purely by specific educational goals. However, the stabilization was only "on paper"; in fact, the system suffered from acute shortage of qualified personnel capable of teaching musical subjects. The academic performing was taught in the middle grades of a secular school: in the gymnasium of Krasnoyarsk (year of opening: 1868) and Yeniseisk (1905), schools for girls in Krasnoyarsk (1878), Yeniseisk (1881), Kansk, Achinsk, Minusinsk (early twentieth century), teachers' seminaries in Krasnoyarsk (1873) and Minusinsk (1913). The atmosphere in those institutions was relatively free, but nevertheless, music performing evolved mainly due to internal self-organization processes: the musical disciplines were governed by the rules of each institution, the attitude of administration, the desire of students, the presence of qualified and initiative teachers.

\section{FORMING OF PROFESSIONAL MUSIC EDUCATION IN YENISEISK PROVINCE IN THE SOVIET PERIOD}

The establishment of the Soviets led to fundamental changes in the entire national system of academic traditions. Bolsheviks art was seen as a powerful tool to influence public consciousness and the translator of the new ideology, and its main function, in addition to education, was the propaganda. Professional music culture at that time was ruled by authorities who deliberately put into practice theoretical principles of socialism. One of the priorities was the democratization of academic art and active involvement of the masses. Qualified professionals - musicians, artists, educators, and amateur managers were in urgent need. In the early 1920s, Siberia's number of music schools rapidly grew.

Soviet government established itself in the capital of the Yeniseisk Province in January 1920. The main goal of that period was "the opening of music schools available to the working class". The idea of People's Conservatory, as it was written in local newspapers - the "new proletarian music institution," [10] - in Krasnoyarsk was actively supported by the "old" intellectuals, who had been looking for any possibility of creating a musical educational institution for many years. It should be noted, however, that People's Conservatory was a groundbreaking phenomenon only in Yeniseisk Province, but not in the history of Russian culture. The first People's Conservatory was opened in 1906 by a group of respected musicians in Moscow, Russia (Taneyev S.I., Engel Y.E., Linyov E.E., Nikolayev L.V., Yavorsky B.L. etc.). It was created to "counterbalance" the Moscow Conservatory and became a publicly accessible institution that combined general and professional musical education and existed mainly on donations [19]. The Bolsheviks used the idea that had already been successfully tested and proved in Russia. In the first years of the Soviets the number of People's conservatories in the country increased significantly along with free development of musical culture ${ }^{4}$.

\footnotetext{
4 Along with Russian Musical Society Departments there were the Proletkult functioning in various regions, e.g. in Far East Republic (19201922). In 1920 these two organizations formed a new one - the Proletkult Soviet. In 1917 the People's Conservatory was found in Vladivostok, then a musical college in 1918 and Conservatory in 1922.
} 
People's Conservatory began its work in Krasnoyarsk in April 1920 and was ruled by Ivanov-Radkevich P.I. The first teaching staff consisted of highly qualified professionals and included Russian and European musicians having conservatory education who found themselves in Krasnoyarsk among prisoners and the First World War refugees from Central and European Russia. They joined Siberians in the process of Bolsheviks cultural development, which took place on the current pre-revolutionary platform in the region, using the "old" experience and staff. Krasnoyarsk People's Conservatory combined the features of modern primary and secondary vocational schools and had two departments: instrumental (the program was carried out "on the Russian Musical Society curriculum" [10]), and teaching. The first taught piano, bowed, wind instruments, folk instruments, solo singing, the second - prepared music teachers for rural clubs, singing teachers for secondary schools and organizers of choirs [10]. People's Conservatory in Krasnoyarsk successfully synthesized old and new forms of educational activities, combined traits emanating from its pre-revolutionary prototypes - democracy, accessibility, focus on the masses, wide concert and lecture work, the training of teachers of music and singing for primary schools [19] as well as classes of Russian Music Society - education of performers (instrumentalists, vocalists) able to continue their education in higher educational institutions.

Large organizational work was carried out in the districts of Yeniseisk province: Kansk authorities in 1920 opened a music studio [3. P. 36], and a year later - school [18. P. 236], in Minusinsk in 1921 music school was opened [13. P. 44]. The opening of those educational institutions in Yeniseisk Province was the result of interaction between the aspirations and ideas of the creative intelligent people with repeatedly increased interest and patronage of the government. Professional musical education moved to the area of the most important tasks of the Bolshevik culture and received state support "from above".

Unfortunately, the financial crisis in the Soviet Republic in the early 1920s and the New Economic Policy (NEP) minimized supply of state institutions of culture and education and led to closure of music schools in Kansk and Minusinsk in 1923. In Krasnoyarsk, the People's Conservatory was reorganized into a music college in 1922 and basically "existed on the fees charged from students" [ 2 . P. 9]. It had taken over the function of consolidating the creative center of the Province while preventing the collapse of the current system of academic art. Thanks to the teachers and students, symphonic and choral concerts along with opera performances were held, critical reviews continued to be published in the pages of the local press. The foundation of the main musical educational institution of the Yeniseisk Province in 1920 - People's Conservatory - and its further continuous operation in a variety of forms (technical school, college $)^{5}$ had become a key event in the long process of "rooting" academic traditions in the region.

${ }^{5}$ In 1922 the People's Conservatory was reorganized into Technical School and in 1936 it became a College. This educational institution still operates in Krasnoyarsk.

\section{ACQUISITION OF ACADEMIC MODEL IN} KRASNOYARSK AREA AND THE ROLE OF MUSIC EDUCATION THROUGH THE PRISM OF “CENTER-PERIPHERY” PROBLEM

Expanding the European cultural system and formation of regional academic patterns are inextricably linked with the problem of interaction between the center and the periphery. Multilayer semantic content of "center-periphery" correlative pair in art and culture has led to the intensification of research in the 21 st century; at the same time, new facets of the problems that are discussed in various areas of musical knowledge, including regional studies, have been revealed [6; 21]. In this perspective, it seems important to estimate the role of music educational institutions. Drozhzhina M.N. while studying the processes of formation of the young composers' schools in the light of the problem of the "centerperiphery" lists several stages of relationship within the said binomial that dotted outline principles for the development of musical culture [4. P. 88]. Applying the findings of the scientist to the Krasnoyarsk ethnographic materials we can denote the stages of academic art development in Yeniseisk Province: 1) pulses directed from the outside center (foreign Europe, Central Russia) to the periphery (Krasnoyarsk area); 2) counter centripetal impulses emerge; 3 ) a new center is formed (Krasnoyarsk as a musical-cultural capital of the province) and acquires its own periphery (counties). Keeping in mind the non-linearity of cultural development (as opposed to technical progress), it is possible to see how the main musical educational institution of Yeniseisk Province People's Conservatory - influenced the relationship between center and periphery in the context of each of the above stage indicated.

The educational institution provided creative and financial conditions for stable work of highly educated immigrants living in Krasnoyarsk. After the foundation of People's Conservatory the flows of Siberians directed to Russian musical centers started to vary both qualitatively and quantitatively. And finally, the main thing - thanks to "vocational training for composers and performing on-site staff, a new center has been formed" [4. P. 88]. This stage is the main indicator of development and "rooting" of new musical traditions, and the possibility of its occurrence is dictated by the processes of formation of professional music education in the regions.

People's Conservatory significantly strengthens the position of the province capital as the cultural centre, and its activity was directly involved in the formation of a common cultural space in the region, united with internal motions and having its own center (Krasnoyarsk) and the periphery (counties). People's Conservatory not only provided flows of students from across the province and return movement of qualified personnel but initially assumed the function of ta Philharmonic by organizing concerts in the cities and villages of Krasnoyarsk area. As a result, thanks to the constant work of educational institutions, academic music system of Yeniseisk Province increased its ability to reproduce itself. It rose to a higher level, got more independence and developed not only because of the external "win-win experience circulation" (the term of E. Trembovelskiy) [21] between the metropolis and the 
provinces, but also due to regional, relatively autonomous "circulation". That is why it has become stable and less vulnerable to adverse conditions of formation in the remote regions of the country.

\section{CONCLUSION}

It is quite obvious that music education plays a key role in the process of acquiring academic traditions and formation of local components in new geographical areas. It is the professional music training institutions that made music traditions, once being "foreign" to the Asian part of Russia (in our case, for Siberia), friendly and custom, gave opportunities for their preservation, translation, reproduction and continuity in the region. The culmination of professional music education formation became the creating of a threelevel pyramid which included a network of music schools, colleges and university (Institute of Arts), which was opened in 1978. Every year students of the local educational institutions more and more confidently declare themselves in the national and world cultural space, become rightfully included in the international academic art. At the same time the periphery of Krasnoyarsk has significantly expanded. Centrifugal impulses coming from the city not only have an impact on the spreading and development of academic traditions in Krasnoyarsk Krai, but also affect musical culture of the neighboring republics - Khakasia and Tyva.

\section{REFERENCES}

[1] B.V. Asafiev Musical form as a process. Book 1, 2. Leningrad: Music, 1971.

[2] Report of the Director of the Musical College. Minutes of meetings of the Pedagogical College Board (1926-1927) // GAKK. F. R-137. Op. 1. item 157.

[3] Report on the activities of the Arts subdivision EnGUBONO (1920) // GAKK. F. R-169. Op. 1. Item13.

[4] M.N. Drozhzhina Young national composer schools of the East as a phenomenon of the musical art of the 20TH century. Novosibirsk: Novosibirsk State Conservatory named after M.I. Glinka, 2004.

[5] K. G. Sh. Music classes in Krasnoyarsk // Krasnoyarsk Bulletin. 1910. 12 February.

[6] I.P. Kozlovskaya Thesis: musical life of the Ural province at the beginning of the 20TH century (on the example of the Perm region) end of 19TH century. Novosibirsk, 2008.

[7] V.A. Koroleva Imperial Russian Musical Society and the Proletkult in the Far East: the alliance or confrontation? // Art culture [electronic $\begin{array}{llllll}\text { magazine]. } & 2013 . & № & 2 & \text { (7). }\end{array}$ http://siap.ru/publications/magazines/kultura/authors/582.html

[8] T.G. Kuzmina Musical theater in Minusinsk of the second half of 19TH century // Eurasian union of scientistp. 2015. № 8 (17), pp. 105-108.

[9] D.S. Likhachev The development of Russian literature in X-XVII centuries. Saint-Petersburg: Science, 1999.

[10] People's Conservatory (From the report of the Head IvanovRadkevich P.I.) // Krasnoyarskiy Rabochy. 1920. -4 of March.

[11] About our Musical Society // Krasnoyarsk Gazette. 1910. 11 April.

[12] Report of the Krasnoyarsk society of music and literature lovers for the 1888-1889 concert season // Krasnoyarsk Regional Museum of Local Lore (KKKM). o/f 9019/ 5175. PI - Krasnoyarsk: Goshtovtt and Comp, 1889.

[13] Report on the work of the departments EnGUBONO (1921) // GAKK. F. R-93. Op. 1. Item 92. 221 p.
[14] According to the petition of the chairwoman of the Board of Krasnoyarsk music and literature lovers Association with a resolution to open in Krasnoyarsk music and singing classes (1897-1899) // the State Archives of the Krasnoyarsk Krai (GAKK). F. 595. Op. 8. item 2808. $13 \mathrm{p}$.

[15] At the request of the officer Erast Vasilyevich Vostokov about approving the statute of lovers of dramatic art, music and singing Circle (1905) // The State Archives of the Krasnoyarsk Krai (GAKK). F. 595. Op. 3. Item323. 6 p.

[16] At the request of the Board of the Yeniseisk society of music and literature lovers on the resumption of its activities (1907) // the State Archives of the Krasnoyarsk Krai (GAKK). F. 595. Op. 3. Item928. 7 p.

[17] E.V. Prygun Musical culture of Krasnoyarsk (1628-1920) // Musical Culture of Krasnoyarsk:. 3 vol. Krasnoyarsk: KGAMiT, 2009. T. 1: 1628-1920, pp. 8-171.

[18] E.V. Prygun The development of the initial stage of music education in Krasnoyarsk from 1920 until the end of the 70-ies of 20TH century // The musical culture of Krasnoyarsk: 3 volumes - Krasnoyarsk:. KGAMiT, 2011. - T. 2: 1920-1978, pp. 232-345.

[19] I.N. Suetin Features of the organization of vocational education in music People's conservatories in Russia in the early twentieth century (Simbirsk Province example) // Kazan pedagogical journal. - 2011. № 3, pp. 156-161.

[20] Theatre and Music // Yenisei.1899. April 7. № 41.

[21] E.B. Trembovelskiy Organization of Russian cultural space: the ratio of center and periphery // Musical Academy. 2003. № 2, pp. 132-137.

[22] Charter of Yeniseisk society of music and literature lovers // Yeniseisk local museum. Kytmanov A.I. (EKM). o/f 5612. Yeniseisk: Gryaznov A.E. Typography, 1899. 12 p.

[23] L.I. Firsankova Theatre in Kansk 1907-2007: History of Kansk City Drama Theater. Krasnoyarsk, 2007.

[24] E.S. Tsareva Musical life of Krasnoyarsk from the beginnings until 1922: Ways of formation musical culture of European type. Krasnoyarsk: KGAMiT, 2014.

[25] B.A. Shindin Musical culture of the city in the context of typological approaches // Musical culture of the city as an artistic and social problem: scientific conf. materials digest (11-14 April 2011). Novosibirsk State Conservatory named after M.I. Glinka, 2011, pp. 520.

[26] A.R. Schneider The population of Yeniseisk Province. Krasnoyarsk: Publication of Bureau of Local History at the Mid-Siberian department of Russian Geographical Society, 1928. 23 p. 